\title{
THE INDIRECT COSTS OF FINANCIAL DISTRESS IN INDONESIA*
}

\author{
Wijantini
}

This paper presents quantitative estimates of the indirect cost of financial distress and its determinants. In order to measure the cost, this study estimates the annualized changes in industry-adjusted operation profit and sales from a year before the onset of distress to the resolution year. Using those approaches, the median of indirect financial distress cost is estimated between three and 11 percent annually. To the extent that the direct cost of financial distress reduces reported operating income, the estimated costs are overstated. The simple regressions analysis suggest that the indirect cost of financial distress significantly increases with size, leverage, number of creditors, and poor industry performance, but is not related to degree of bank loan reliance. The findings provide a weak support for the financial distress theory which suggests that conflicts of interest render the costs of financial distress.

Keywords: conflicts of interest; indirect cost of financial distress; industry factor

\footnotetext{
*) Acknowledgement: This paper is based, in part, on my thesis completed at the University of Birmingham, UK. I am indebted to my supervisor, Dr. T.A Adedeji for his valuable comment.
} 
Gadjah Mada International Journal of Business, May - August 2007, Vol. 9, No. 2

\section{Introduction}

The existence of total financial distress costs is a critical argument in corporate finance issues, such as optimal capital structure, firm valuation, and risk management. The initial work of Modigliani and Miller $(1958,1963)$ trigger seminal arguments on the importance of these costs. It is deeply embedded in most of the theoretical works of the authorities in this field (Kraus and Litzenberger 1973; Scott 1976; Castanias 1983; White 1983).

The objectives of this paper are, first, to estimate the indirect costs of financial distress in Indonesia. Capital structure theories give contradictory suggestions on whether the costs of financial distress are trivial (Modigliani and Miller 1958, 1963) or non-trivial (Myers and Majluf 1984). The estimates of indirect costs of financial distress obtained are used to determine which of these contradictory theoretical views is more relevant to Indonesia. Second, it purports to compare the estimates of indirect costs of financial distress obtained for Indonesia with similar estimates that were reported for the US. Estimates of the costs of financial distress that have been reported in the literature were obtained mainly with U.S. data. The results of comparison are beneficial for assessing the relevance of the estimates to a developing economy like Indonesia. Finally, the other objective is to test the firm characteristics, which previous studies suggest to be the determinants of cross-sectional variation in the costs of financial distress in the U.S., on the firms in Indonesia, and to examine whether the impacts of the firm characteristics in Indonesia are similar to those reported in the U.S.

\section{Brief Literature Review}

Financial distress is a situation where firms cannot service their current debts. Financially distressed firms have to meet more costs than do normal firms. The costs may reduce firm value and conventionally consist of both direct and indirect costs. If firms at this state reorganize under court supervision and opt for liquidation, they may incur even higher direct costs than if they reorganize privately (Gilson, John, and Lang 1990). The values of their assets may go down progressively while waiting for liquidation. In addition, they will also indirectly be burdened by the costs imposed by customers, suppliers, and capital providers as a result of financially distressed condition and nonoptimal managerial actions during the period of distress. Firms' bad performance leads managers to lose time in formulating and communicating reorganization plans to their stakeholders. Hence, the total indirect costs of financial distress are potentially great and occur whether or not the firm actually defaults (Chen and Merville 1999).

Previous studies tried to find how high the costs of financial distress were, especially those related to the use of the costs in the capital structure theory. Some empirical studies estimate the 
costs of financial distress as any reduction in the value of output in the real world relative to the hypothetical best world. Critiques appear to the measurement due to the lack of distinction between ex-ante and ex-post distress costs. The importance of ex-ante distress cost should be addressed if it is to be applied in such a theory. Other studies divide the costs into three types, which are associated with the behavior of managers of failing firms who attempt to avoid or delay filing for bankruptcy. They can result from overinvestment, under-investment, or the delay effect, all causing additional expenses. Financial distress also happens as a result of a mismatch between the currently available liquid assets of a firm and its current obligations under its financial contracts. To solve such mismatch problem, firms are supposed to restructure the assets and/or restructure the financing contracts. Restructuring the asset means that firms may convert illiquid assets to liquid ones, whereas restructuring the financial contracts relates to debt restructuring. In other words, the costs of financial distress are costs related to corporate liquidity policy and leverage policy. When the costs are high, firms may maintain a larger fraction of their as- sets as liquid assets and/or incur debt cautiously.

Economic researchers often find difficulty measuring the "pure" costs of financial distress. The difficulties come from an inability to distinguish whether the poor performance of a firm in financial distress is caused by the financial problem per se or is caused by factors which originally push the firm into financial distress, e.g., economic problems or fraud. Andrade and Kaplan (1998) offer the "pure" measurement of financial distress by using sample with positive operating income as evidence that the sample is not economically distressed firms, but firms which suffer from negative earnings after paying debt interest. The authors claim that their sample contains purely financially distressed firms, and for this reason they call their measurement 'costs of financial distress'. Measuring the costs of financial distress is done by comparing the estimated capital value of the distressed firm at the end of the year before the onset of distress to the capital value realized through the resolution of distress. Table 1 summarizes previous research on the costs of financial distress in various sample, methods, and results. 
Gadjah Mada International Journal of Business, May - August 2007, Vol. 9, No. 2

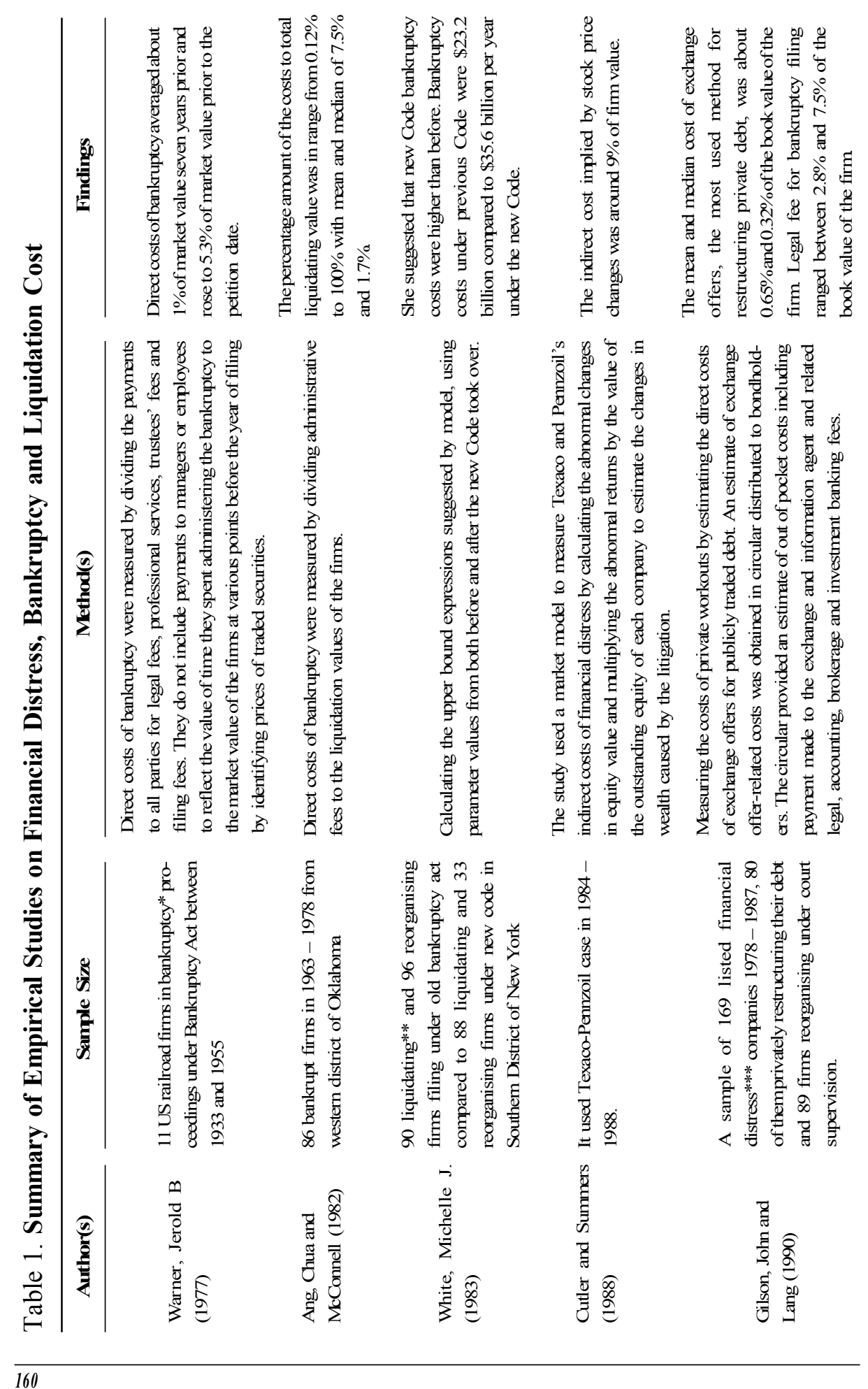


Wijantini-The Indirect Costs of Financial Distress in Indonesia

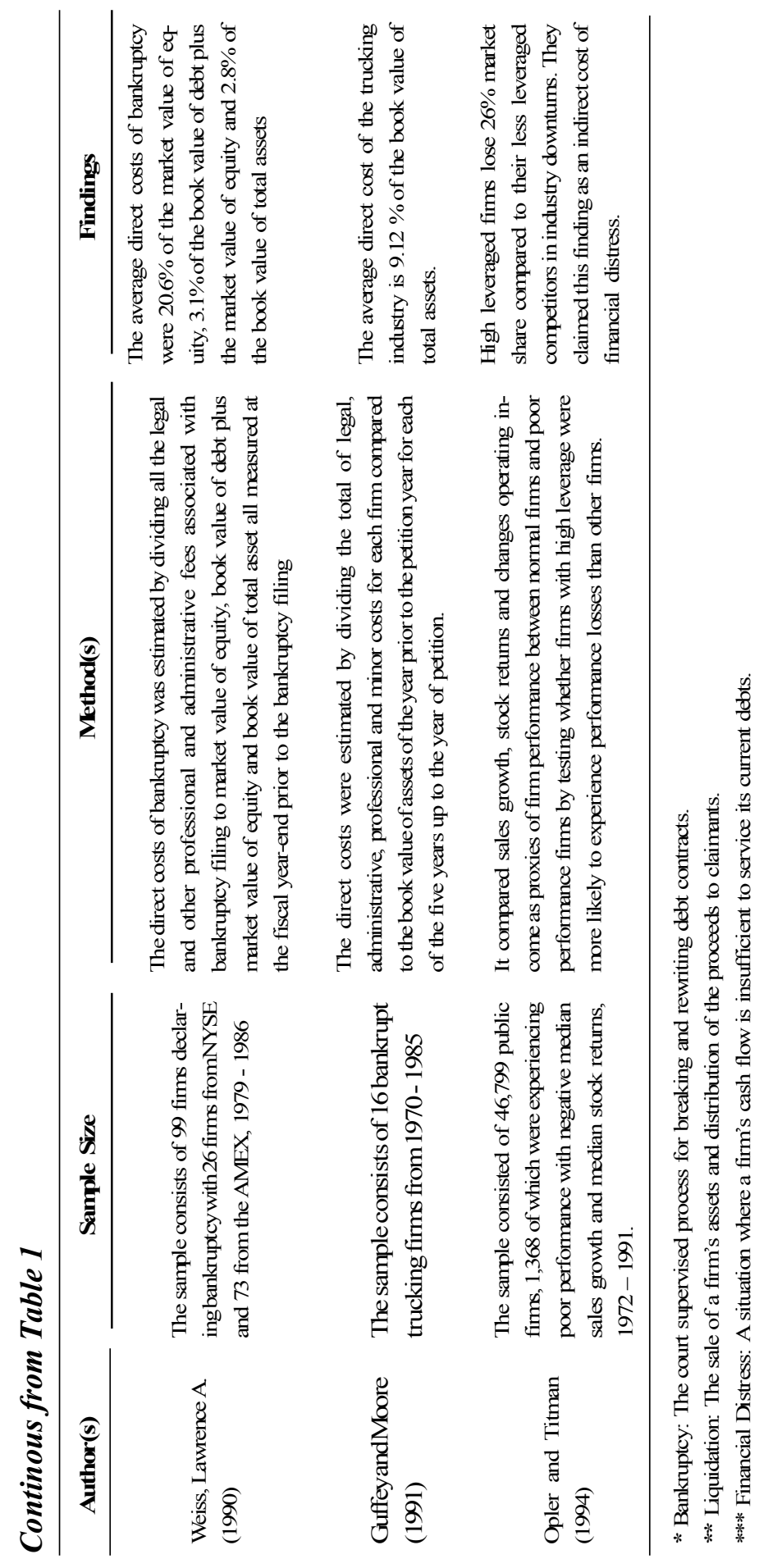


Gadjah Mada International Journal of Business, May - August 2007, Vol. 9, No. 2

The Indirect Costs of Financial Distress

\section{Explanatory Variables}

Figure 1 presents the explanatory variables of financial distress costs. The dependent variable in this model is the indirect costs of financial distress. The total costs of financial distress are defined as the reduction in value due to a perceived inability to honor future fixed payments and the potential for subsequent bankruptcy proceedings (Branch 2002). The independent variables are grouped according to the construct's organizational characteristics, conflicts of interest, and industry factors. First, the organizational characteristics refer to the inter- nal characteristics of distressed companies. This construct consists of two independent variables: size of company and leverage. Second, the conflicts of interest refer to potential problems raised between principals and agents during the period of distress. These involve three independent variables: time in distress, capital structure complexity, and degree of bank loans. However, size and leverage can also be proxies for information asymmetry which has a positive association with the conflicts of interest. Finally, the industry factors refer to market conditions which may affect the indirect cost of financial distress. The variable is the illiquid market.

\section{Figure 1. Factors Affecting the Indirect Costs of Financial Distress}

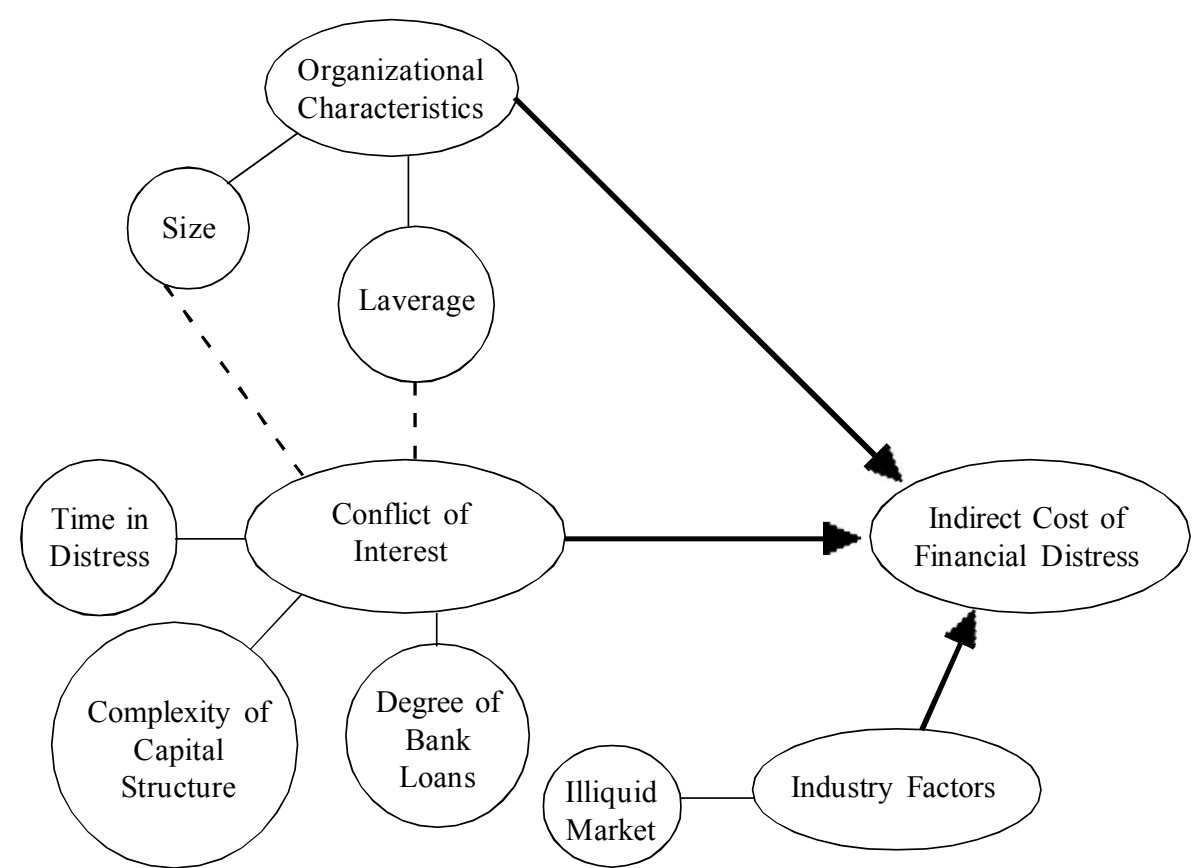

Source: Author's classification based on various studies. 
Wijantini-The Indirect Costs of FinancialDistress in Indonesia

\section{Hypotheses Development}

Size of Company and the Indirect Cost of Financial Distress

In theory, small firms have bigger problems in accessing capital because of the asymmetric information between insiders and outsiders. The difficulties become severe when the likelihood of liquidation arises. However, managing large firms during the period of financial distress may be costly since its more complicated internal organization requires implicit contracts which may be difficult to enforce during difficult times (Noveas and Zingales 1995).

Financial distress theory suggests that conflicts of interest positively affect the extent of costs. Bigger size may represent higher level and more complex conflicts of interest, making it more difficult for claimants to agree over resolving the distress. Complexity also relates to the time spent in financial distress. The costs increase with time because the value of firms declines as claimants expend resources arguing over a fair resolution of the distress (Helwege 1996; Andrade and Kaplan 1998). Moreover, bigger companies may positively relate to bigger bank loans received by distressed firms. The number of bank creditors is also more likely to increase with the amount of loans. Given the possibility of higher conflicts in distress resolution as the number of creditors increases, the following hypothesis is tested:
H1: Size of a firm is positively related to the indirect cost of financial distress

\section{Leverage and the Indirect Cost of Financial Distress}

In arguments which began with the seminal work of Modigliani and Miller $(1958,1963)$, it is specifically expected that financial distress costs prevent firms from using high leverage. The reason behind this is that capital providers of higher-leverage firms will increase their required rates of return due to the higher expected cost of financial distress. The trade-off between expected distress costs and expected tax shield benefits yields an internal solution for optimal capital structure.

Opler and Titman (1994) give evidence that there is a positive relationship between financing structure and firm performance in industry downturns. They reveal that more highly leveraged firms tend to lose market share and experience lower operating profits than do their competitors in industry downturns. This indirectly suggests a positive relationship between leverage and lost market shares since one of the measurements of financial distress costs is by calculating the changes in corporate performance. Prior studies applied changes in sales, investment, and operating income from the year before the onset of distress to the resolution year as the measures of the costs of financial distress (Altman 1984; Chen and Marville 1999; 
Andrade and Kaplan 1998, among others).

Managers estimating the expected costs of financial distress believe that higher leverage leads to a higher probability of distress, and may positively influence costs. In Miller and Modigliani's influential model, leverage is recognized as a proxy for distress cost. However, it is unclear whether the leverage itself directly affects the realized distress costs or this is endogenous to agency problems. Higher leverage may correlate to time in distress, capital structure complexity, and the ease of restructuring. In other words, higher leverage may increase the conflicts between claimants and affect the indirect cost of financial distress. This leads to the second hypothesis to be tested.

H2: There is a positive relationship between leverage and the indirect cost of financial distress

\section{Capital Structure Complexity and the Indirect Cost of Financial Distress}

In financial distress theory, it is the bargaining problem which mainly creates inefficiency. As a firm's capital structure attracts more securities and becomes more complex, it adds problems owing to higher conflicts of interest and agency problems. Bulow and Shoven's model (1978) explains the potential conflicts of interest among various claimants. The complexity of claimants makes it more difficult for distressed firms to agree on restructur- ing values. Stone (1977) suggests that the complexity of the financial structure, such as the number of issues and nature of claims, may explain bankruptcy costs. Bargaining opportunities are expected to slow down the restructuring process as the number and types of claimants involved increase. Furthermore, Modigliani and Miller's seminal works reveal that the conflicts of interest and free-rider problems are factors related to firms' borrowing ratios. They suggest that higher leverage leads to higher agency costs on account of holdout problems. Holdout problems are associated with the higher number and more complicated types of creditors.

Most publicly listed companies in Indonesia utilize bank loans extensively, and rely less on capital markets in funding their capital. Previous studies commonly used the number of securities as the proxy for capital complexity. Since this proxy may not apply to Indonesian sample, we apply the number of different creditors as the proxy for the complexity of capital structure. Thus, we expect that the number of bank lenders increases with conflicts of interest and accordingly with the indirect cost of financial distress.

Moreover, one specific factor which may affect the costs of financial distress is the condition of banks that lend out money at the onset of distress. If the main bank is faced with serious problems of liquidity and subsequently liquidated, taken over, or merged with another bank, it may affect the rela- 
tionship between debtor and lender, leading to higher indirect cost of financial distress. The following hypothesis will examine the association between the number of bank lenders and the indirect cost of financial distress.

H3: There is a positive relationship between the number of bankslending to a distressed firm and the indirect cost of financial distress.

\section{The Degree of Bank Debt Reliance}

Gilson, John, and Lang (1990) find that firms with greater reliance on bank debt are more likely to resolve financial distress through out-of-court resolution. They also suggest that these firms restructure sooner (11 months) than do those which restructure under formal bankruptcy (21 months). They suggest that banks lead their clients out of default more quickly, meaning that the presence of bank debt improves a firm's ability to restructure. Andrade and Kaplan (1998) included a variable which measures the ratio of debt, and their findings support Gilson, John and Lang's (1990) result. Their cross-sectional results indicate that a greater fraction of bank debt reduces the costs of financial distress by 10 percent significance. However, two other proxies, the presence of public junk bonds and a buyout sponsor, have no effect on the costs of financial distress. In a study analyzing junk bond defaults, Helwege (1999) finds a contradictory result, which is the greater the fraction of debt owed to banks, the slower the renegotiation process.
Under easier bargaining conditions, distressed firms may resolve their problems quicker; hence, ease of restructuring correlates with time in distress. Previous studies suggest that time in distress has a positive association with the costs of financial distress. The basic argument is that time in distress relates to the costs of financial distress because the claimants might expend the firm's resources over time. The quicker the problems of a distressed firm are resolved, the better will be the value of the firm. Similar theory suggests that bargaining and coordination problems may slow down the restructuring process (Giammarino 1989; Gertner and Scharfstein 1991, among others). Moreover, negotiations may also be more difficult when there are wider information asymmetries among the claimants.

Jensen (1991) argues that the costs of financial distress have a positive relationship with the length of time in distress. Jensen points out that some bankruptcy resolutions may help distressed firms to accelerate their distress resolution, for instance, offering pre-packaged bankruptcies or a facilitator in exchange offer. However, Haugen and Senbet (1978) argue that under a well-functioning market, with a large number of buyers, price-takers and rational sellers and creditors, claimants' bargains are nearly costless in a competitive market; therefore, the overall firm value is not affected. If distressed firms fail to repay their scheduled debts, they may avoid the costs of financial distress by "switching" the 
ownership from equity-holders to debtholders or conducting a merger with another firm. In order to avoid problems from market impediments, they suggest that the firms make simple provisions to incorporate charters and bond indentures when they issue debt capital.

Andrade and Kaplan (1998) support Haugen's idea, and claim that there is no association between time in distress and the costs of financial distress. However, they provide details of the period of distress for their sample, and report the average time in distress of 44 months, measured from the beginning of the year of distress onset to the month of distress resolution, varying from 24 months to more than 60 months. Helwege (1999) also shows no significant effect of firm value or lost growth opportunities on the time in default. She mentions that this reflects the lack of a clear relationship between time-in-default and decreases in firm value as one of the measurements of financial distress costs.

In an early study of bankruptcy cost, Warner (1977) reports no relationship between the length of time spent in bankruptcy proceedings and firm value. Hence, high-market-value firms do not incur higher costs of bankruptcy than do low-market-value firms simply because they stay longer in distress. His research does not directly examine the relationship between time in distress and the costs of financial distress. Several studies present evidence of how long bond defaults or bankruptcy cases last. Altman and
Eberhart (1994) and Betker (1998) report that time in default is generally between two and two-and-a-half years. Altman (1993) and Hotchkiss (1995) estimate the time range of $1.5-2.5$ years. Gilson, John, and Lang (1990) suggest that firms with more bank debt, less complex classes of debt, and fewer tangible assets tend to conduct private workouts. They estimate that the median of informal resolution is only 11 months, compared to the median of formal restructuring of 21 months. In contrast, Helwege (1999) reports that bank debt is associated with slower restructuring. This is consistent with Asquith, Gertner, and Scharfstein's (1994) view that banks do not facilitate the resolution process, and even appear to slow down renegotiations. Her analysis shows that firm size, lawsuits, and the presence of contingent claims are significant factors lengthening the default time.

Moreover, Gilson, John, and Lang (1990) suggest that the costs of financial distress of firms which restructure privately are lower than those of firms which file under bankruptcy chapters in the USA. Under private renegotiation, the distressed firms significantly reduce legal fees because the procedural demand and legal complexity in bankruptcy processes increase legal costs. They also show that shareholders are systematically better off when the debt is restructured privately.

Hoshi et al. (1990) show that financial distress is costly for firms where significant conflicts among creditors are likely. The closed financial links in 
Japanese main-bank relationships may reduce the costs of financial distress. In addition, by taking a sample of highly leveraged transaction firms in the U.S., Andrade and Kaplan (1998) provide evidence that a greater fraction of bank debt reduces costs. Their study suggests that a higher proportion of bank debt improves a firm's ability to renegotiate or restructure. The problems are especially severe for firms that issue publicly traded bonds. In the U.S., the financial markets offer stronger market structures than do those in Indonesia. Hence, without systemic crisis and more sophisticated capital markets, U.S. firms have more choices in resolving their financing problems.

Even though the Indonesian distressed firms prefer to resolve privately, this is not associated with higher reliance on bank debt as it is in the U.S. Rajan and Zingales (1998) suggest that firms in less developed markets are more likely to rely on bank loans as the main source of funding. Referring to current judicial systems in Indonesia, the informal mechanism will not work properly unless there is an easy resort to the court should there be a breakdown in negotiations (Tomasic 2001). Without the legal threat, firms are less likely to resolve promptly. Therefore, higher reliance on bank debt may not reduce the time or the costs of distress. Further, the Asian systemic crisis also affects the banking industry, and the banks have also encountered distress problems. This condition leads to an additional issue: resolving corporate distress due to banks' collapses. A higher degree of bank reliance may be positively associated with the number of bank creditors; hence, it may increase conflicts among banks. Given the issues above, the following hypothesis is tested.

H4: There is a positive relationship between the degree of bank debt reliance in distressed firms and the indirect cost of financial distress

\section{Industry Performance and the Indirect Cost of Financial Distress}

There are debates over bankruptcy law reform regarding the time allowed for selling the assets of distressed firms. Some scholars argue that insolvent firms should be forced into immediate cash liquidation (Baird 1986). This may refer to U.K. bankruptcy law, of which some studies point out premature liquidation as one of the disadvantages. Nevertheless, others object to this contention, arguing that premature liquidation may fail to maximize the proceeds for the liquidating claimholders (Aghion and Bolton 1992). They argue that problems associated with raising capital and the lack of competition for distressed firms' assets will lead the liquidating firms to dispose of assets at a discount.

Shleifer and Vishny (1992) consider the scenario where a firm responds to financial distress by selling assets. They identify three factors determining the market liquidity of the firm's assets. The first is the number of 
Gadjah Mada International Journal of Business, May - August 2007, Vol. 9, No. 2

potential buyers in the market; the second is the characteristics of the assets being sold. If the assets are industryspecific, an inside buyer is likely to value the assets more highly than an outsider. However, even if the inside buyer is more likely a higher bidder, the selling firm may sell the assets to an outsider when the industry itself is in trouble. When firms encounter trouble in repaying debts, and attempt to sell their assets, the highest valuation of these assets are likely given by other firms in the same industry. The third is the financial condition of the industry. If the industry where the firm operates is distressed, it will affect the liquidity of the assets; a poor financial condition in an industry will increase the liquidity premium of assets. The premium may be reduced if the assets are used in other industries. However, the industry outsiders who may not know how to manage them will encounter agency costs of hiring specialists to run the assets, and fear for overpayment since they have no knowledge of the assets' values. When there is no industry buyer to buy the assets, and the only buyers are industry-outsiders, they will charge significant fees for managing and acquiring the assets. Consequently, the prices of the assets will be depressed. This type of cost can be classified under the indirect cost of financial distress. Thus, the total costs of financial distress are likely to be higher among firms with illiquid assets.

Among empirical studies, Kruse (2002) supports Shleifer and Vishny's (1992) asset liquidity model that the prices which distressed firms receive for their assets are based on industry conditions. In particular, the distressed firm is forced to sell assets for less than their full values to industry outsiders when other firms in the same industry are also experiencing difficulties. He conducted his analysis by applying the logistic regressions of the probability of assets sales by poorly performing firms. The study controlled other factors which were previously identified to be related with the probability of assets sales by poorly performing firms. The study defined distressed firms as firms suffering from a dramatic decline in operating performance. The findings confirm a positive relation between an industry's growth rate and the likelihood of assets sales by firms in this industry. In addition, the results indicate that firms operating in fastergrowing industries are receiving the reservation prices for their assets.

Pulvino (1998) also agrees with the model of Shleifer and Vishny (1992) that discount assets are sold in depressed industries where the assets are industry-specific. He used commercial aircraft transactions to test the relationship, and finds that financially constrained airlines liquidate aircrafts at discount to fundamental values, and are more likely to sell used aircrafts to industry outsiders. Moreover, airlines with high spare debt capacity tend to buy more used aircrafts than do airlines with low spare debt capacity, particularly when aircraft prices are depressed. In addition, Pulvino also supports Vishny and Schleifer's model 
that the prices which sellers accept for their assets depend on the costs of raising capital. Airlines with high leverage ratios and low current ratios receive lower prices for their assets than do more conservatively financed airlines. This indicates that buyers consider a higher discount rate for riskier assets.

Brown (2000) also finds similar evidence from Real Estate Investment Trusts (REITs). His study shows asset illiquidity in an industry downturn and significant financial distress costs for highly leveraged firms during the downturn. Moreover, owner-manager entities may be particularly large because lenders' incentives to reorganize to avoid a foreclosure sale in a depressed market are limited. Kim (1998) measures asset liquidity in the contract drill industry by focusing on the depth of buyers' market and trading volumes, and finds that the characteristics of assets matter. He claims that drilling rigs are less liquid than oilwells. Moreover, his study also indicates that managers generally sell liquid assets before illiquid ones.

When firms have difficulties meeting debt repayments and sell assets or are liquidated, the highest valuation of these assets is likely given by other firms in the industry. However, these firms are likely to have troubles meeting their debt payments when the assets are put up for sale, for this is when the shock causing the seller's distress is industry-or economy-wide. When systemic crisis attacks the East Asian countries, the industry buyers are un- likely to be able to raise funds for buying the distressed assets. If the industry buyers cannot buy the assets and industry outsiders encounter significant costs of acquiring and managing the assets, the assets in liquidation will be sold at depressed prices. The poor financial condition of an industry will increase the liquidity premium in such sales. Although the premium may be reduced when the assets are usable in other industries, asset-restructuring costs are likely to be high if the market for used assets is illiquid. The following hypothesis will then be tested:

H5: There is a negative relationship between industry performance and indirect cost of financial distress

\section{Sample Description}

\section{Identifying Financially Distressed Firms}

To be included in the sample, firms must satisfy several criteria. Panel A in Table 2 describes the screening procedures used to collect the financial distress sample firms. First, they had an interest coverage ratio of between 0 and 1 for at least one year between 1997 and 2002. The interest coverage ratio was calculated from Datastream by dividing operating profit before interest expense, income taxes, depreciation and amortization by interest charges. In this case, the interest charges (Datastream code number: 2408) represent the aggregate value of interest paid less interest received. The sample contains non-financial firms only, and 
Gadjah Mada International Journal of Business, May - August 2007, Vol. 9, No. 2

Table 2. Sample Selection

\begin{tabular}{|c|c|c|c|c|}
\hline $\begin{array}{l}\text { Panel A: } \\
\text { Sample Selection Process }\end{array}$ & $\mathbf{n}$ & \multicolumn{3}{|c|}{$\begin{array}{l}\text { Panel B: } \\
\text { Sample Distribution by Year }\end{array}$} \\
\hline \multirow{2}{*}{$\begin{array}{l}\text { Public listed firms in Jakarta Stock } \\
\text { Exchange in 1997-2002 }\end{array}$} & \multirow[b]{2}{*}{311} & Year & Onset Distress & $\%$ \\
\hline & & 1007 & & \\
\hline Firms in financial or insurance industries & $(42)$ & 1991 & 1 & 24.2 \\
\hline Firms with interest coverage (EBITDA/ & & 1998 & 16 & 55.2 \\
\hline Interest) not between 0 and 1 & $(229)$ & 1999 & 3 & 10.4 \\
\hline \multirow{3}{*}{$\begin{array}{l}\text { Firms with an incomplete or missing } \\
\text { series of annual reports due to lack } \\
\text { of data or being private }\end{array}$} & \multirow{3}{*}{$(5)$} & 2000 & 3 & 10.4 \\
\hline & & 2001 & 0 & 0 \\
\hline & & 2002 & 0 & 0 \\
\hline $\begin{array}{l}\text { Firms without auditor confirmation } \\
\text { of debt renegotiation }\end{array}$ & (6) & Total & 29 & 100.00 \\
\hline Total firms rema & 29 & & & \\
\hline
\end{tabular}

40 firms meet this criterion. Other reasons, for instance, incomplete data or a missing series of annual reports (one firm) and four firms in the sample going private in the year before the onset of distress, reduce the number of firms in the sample to 35 . The onset year is the year when firms for the first time have an interest coverage ratio of between 0 and 1 , and conduct debt restructuring (Wijantini 2006).

An interest coverage ratio of between 0 and 1 does not mean that firms will necessary become financially distressed, which is having difficulties fulfilling the covenants in their debt contracts. Debt payment can be made from other sources than operating income for firms have many options to obtain cash needed to avoid default, including utilizing cash reserves, reducing inventory levels, extending trade creditors, drawing upon bank lines of credit, restructuring debt payments prior to default, raising equity, and selling assets (Whitaker 1999). Therefore, the following additional criteria should be considered to determine the onset of distress. The auditor disclosure in the notes to financial statements must indicate that the firms are negotiating with their creditors to restructure their debts in order to avoid a default. Debt restructuring is defined as an exchange of financial claims which a firm makes to avoid defaulting on its debt, including exchanges such as maturity extensions (Gilson 1990). After this screening, six firms were not supported by restructuring news, and the remaining sample contains 29 financially distressed firms.

Panel B of Table 2 offers sample distribution annually. Most of the firms (16) plunged into financial distress for the first time in 1998 (55.2 percent). 
Seven firms renegotiated their loans with their creditors in 1997, and the remaining firms in the sample rescheduled their debts for the first time in 1999 and 2000.

\section{Research Design}

All hypotheses are examined by regressing an estimate of the indirect cost of financial distress (CFD) on size (SIZE), leverage (LEV), industry performance (DLOW), number of creditors (COMPLEX), and bank debt reliance (BANK). Due to data availability, this paper does not apply time in distress variable as a proxy for conflicts of interest. The following regression equation is applied:

$$
\begin{aligned}
\text { CFD }_{\mathrm{t}}= & \gamma_{0}+\gamma_{1} \text { LSIZE }_{\mathrm{t}}+\gamma_{2} \text { LEV }_{\mathrm{t}}+ \\
& \gamma_{3} \text { COMPLEX }_{\mathrm{t}}+ \\
& \gamma_{4} \text { BANK }_{\mathrm{t}}+ \\
& \gamma_{5} \text { DLOW }_{\mathrm{t}}+\varepsilon_{\mathrm{t}}
\end{aligned}
$$

Each firm's estimated indirect cost of financial distress $\left(\mathrm{CFD}_{\mathrm{t}}\right)$ is calculated from the changes in operating and sales performances. The procedure used to measure this variable is described later. SIZE $E_{t}$ is the market value of outstanding total capital at the onset of distress as a proxy for company size. The log value of SIZE $_{t}$ (LSIZE) is included in the analysis because the association between SIZE ${ }_{t}$ and $C F D_{t}$ was previously identified as a non-linear relationship. $\mathrm{LEV}_{t}$ is the ratio of total debt to total capital at the onset of distress. DLOW $t$ is 1 if the industry's return on sales is in the low quartile (below $25^{\text {th }}$ percentile) over the period when indirect cost of financial distress is calculated, 0 otherwise. The industry's return is equal-weighted returns to firms in the same industry over the period when the indirect cost of financial distress is calculated. COMPLEX ${ }_{t}$ is the number of firm's creditors at the onset of distress. BANK is the portion of bank loans to total debt at the onset of distress.

\section{Measuring the Indirect Costs of Financial Distress}

To measure the indirect cost of financial distress, this study applies changes in operating profit and sales, adjusted to industry from a year before the onset of distress year to the year of resolution (Opler and Titman 1994; Andrade and Kaplan 1998). After conducting data collection, we find that some firms were still in distress at the end of 2002. These firms had their costs measured by annualizing the changes in operating profit and sales from a year before the onset of distress to the end of 2002. The main reason that this study includes such firms is to increase the number of firms in the sample. We present their cost estimations separately in different categories.

The above approach refers to the seminal works of Miller and Modigliani, illustrating that company value may decrease accordingly when there is a higher possibility of financial distress. In their model, higher leverage causes a higher probability of fi- 
nancial distress. Value in a year before the onset of distress represents the true value while value at the distress resolution represents the reduction due to financial distress.

If the value at the end of distress resolution is less than the value one year before the onset of distress, it reflects the extent of financial distress costs, which refer to the drop in value due to the financial distress. It may also represent the indirect cost of financial distress which we believe to be the biggest portion of financial distress costs since the predicted direct cost of financial distress in Indonesia is very low.

Furthermore, the costs were estimated by industry-adjusted operating profit and sales, with the following procedures. First, the changes in each firm's performance were computed. Then the changes in the median industry firms' performance for all firms in the same industry were calculated for each year for each firm in the sample, and this number was then subtracted from the changes in performance. For those firms having a resolution year, the annualized changes were from a year before the onset of distress year to the resolution year, while for those firms that were still in distress, the average changes from a year before the onset of distress year to the end of 2002 were calculated.

We try to estimate the changes in value of financially distressed firms by applying the comparable company method (Kaplan and Ruback 1995). However, the bias in the results makes the approach untrustworthy. For instance, for those 11 firms which had an exit year, the median (mean) estimated costs of financial distress were 0.8 (14.8) with a standard deviation of 27.8. Under turbulent conditions, the comparable company's approach may lack precision due to future uncertainty in the company and industry. Hence, we do not report the results of the estimation.

\section{Results and Discussion}

To interpret the results of the costs estimation, three assumptions are required (Andrade and Kaplan 1998). First, it assumes that a change is permanent and translated into a permanent drop in firm performance. Second, for firms having a distress resolution year, it assumes that the study has accurately identified the start and end years of the distress. For the firms which were still in distress in 2002, the estimate may understate the costs, since the firms' operating profits may deteriorate further. Finally, the study attempts to capture firms which suffered from financial distress through sample screening, even though it is very difficult to purify the screening from economic shock.

Table 3 presents the annualized estimation of financial distress costs in Indonesia. The results are presented in five categories based on the year in distress. Panel A presents eight companies which were financially distressed in 1997 and 1998, and resolved their debt renegotiation by 2002 . The 
Wijantini-The Indirect Costs of FinancialDistress in Indonesia

\section{Table 3. The Estimated Indirect Costs of Financial Distress}

Panel A: Firms which were financially distressed in 1997 and 1998 and exited from the distress by 2002

The Indirect Costs of Financial Distress (CFDop) are estimated by annualised changes of industry adjusted operating profit (EBITDA/Total Sales) from a year before the onset of distress to the exit year. CFDs are estimated by annualised changes of industry-adjusted sales from a year before the onset of distress to the exit year. Negative (positive) signs indicate lower (higher) adjusted performance at the exit year, therefore showing the costs (value creation) estimation.

\begin{tabular}{|c|c|c|c|c|c|c|}
\hline No. & Company & $\begin{array}{c}\text { Industry Classification } \\
\text { (Datastream) }\end{array}$ & $\begin{array}{c}\text { Onset } \\
\text { Distress } \\
\text { Year }\end{array}$ & $\begin{array}{c}\text { Exit } \\
\text { Distress } \\
\text { Year }\end{array}$ & CFDop & CFDs \\
\hline 1 & Astra Graphia & Diversified Industry & 1998 & 2000 & -0.10 & -0.29 \\
\hline 2 & Charoen Pokphand & Farming and Fishing & 1998 & 2000 & -0.13 & -0.53 \\
\hline 3 & Fast Food Indonesia & Food Processing & 1998 & 2002 & -0.02 & 0.20 \\
\hline 4 & Kedawung Setia Ind'l & Household Products & 1997 & 2000 & -0.04 & -0.22 \\
\hline 5 & Lionmesh Prima & Building Materials & 1998 & 2002 & -0.04 & -0.05 \\
\hline 6 & Modern Photo Film & Photography & 1998 & 2001 & 0.00 & 0.03 \\
\hline 7 & Prima Alloy Steel & Autoparts & 1997 & 2000 & -0.03 & -0.07 \\
\hline \multirow[t]{7}{*}{8} & Semen Cibinong & Building Materials & 1998 & 2001 & -0.31 & 0.19 \\
\hline & & MEAN & & & -0.08 & -0.09 \\
\hline & & MEDIAN & & & -0.04 & -0.06 \\
\hline & & QUARTILE 1 & & & -0.11 & -0.24 \\
\hline & & QUARTILE 3 & & & -0.03 & 0.07 \\
\hline & & ST. DEVIATION & & & 0.10 & 0.25 \\
\hline & & $\mathbf{N}$ & & & 8 & 8 \\
\hline
\end{tabular}

Panel B:Firms which were financially distressed in 1997 and 1998, exited from the distress during 1998-2002 and became financially distressed again by 2002

\begin{tabular}{lccc}
\hline No. & Company & $\begin{array}{c}\text { Industry Classification } \\
\text { (Datastream) }\end{array}$ & $\begin{array}{c}\text { Second Onset } \\
\text { Distress Year }\end{array}$ \\
\cline { 1 - 1 } \cline { 5 - 5 } & Kedawung Setia Ind'l & Household Products & 2001 \\
\hline
\end{tabular}


Gadjah Mada International Journal of Business, May - August 2007, Vol. 9, No. 2

\section{Continued from Table 3}

Panel C: Firms which were in financial distress in 1997 and 1998 but still in financial distress by 2002

The industry-adjusted performance is calculated as follows. First, the median change each performance of all firms in the same industry was calculated for each year for each firm in the sample. Then this number was subtracted from the change each firm's performance. The Indirect Costs of Financial Distress (CFDop) were estimated by annualised changes of industry-adjusted operating profit(EBITDA/Total Sales) from a year before the onset of distress to 2002. CFDs are measured by annualised industry adjusted sales changes from a year before the onset of distress to 2002. Sales data for 2002 are directly collected from hardcopies of the annual report while EBITDA data sources are from Datastream. Negative (positive) signs indicate lower (higher) adjusted performance at the exit year, therefore showing the costs (value creation) estimation.

\begin{tabular}{|c|c|c|c|c|c|}
\hline No. & Company & $\begin{array}{l}\text { Industry Classification } \\
\text { (Datastream) }\end{array}$ & $\begin{array}{c}\text { Onset } \\
\text { Distress } \\
\text { Year }\end{array}$ & CFDop & CFDs \\
\hline 1 & Apac Citra & Textiles and Leather & 1997 & 0.02 & 0.68 \\
\hline 2 & Argha Karya Prima & Chemical. Adv. Materials & 1998 & -0.04 & -0.12 \\
\hline 3 & Davomas Abadi & Food Processors & 1998 & -0.03 & -0.20 \\
\hline 4 & Dharmala Intiland & Real Estate Development & 1998 & -0.23 & $\mathrm{n} / \mathrm{a}$ \\
\hline 5 & Indomobil Sukses & Automobile & 1997 & -0.01 & -0.18 \\
\hline 6 & Intraco Penta & Retailers. Multidept & 1998 & 0.00 & 0.02 \\
\hline 7 & Panasia Indosyntex & Textiles and Leather & 1997 & -0.04 & -0.03 \\
\hline 8 & Primarindo Asia & Clothing and Footwear & 1998 & 0.01 & -0.04 \\
\hline 9 & Surabaya Agung & Paper & 1998 & -0.17 & -0.04 \\
\hline 10 & Surya Hidup Satwa & Farming and Fishing & 1998 & -0.09 & -1.12 \\
\hline 11 & Surya Semesta & Building Materials & 1998 & -0.41 & -0.26 \\
\hline 12 & Texmaco Jaya & Textiles and Leather Goods & 1997 & -0.03 & -0.32 \\
\hline 13 & Trias Sentosa Tbk & Chemical. Adv. Materials & 1998 & 0.04 & -0.48 \\
\hline 14 & United Tractors & Commercial Vehicles & 1997 & $\mathrm{n} / \mathrm{a}$ & $\mathrm{n} / \mathrm{a}$ \\
\hline \multirow[t]{7}{*}{15} & Zebra Nusantara & Railroads, freight & 1998 & -0.01 & -0.09 \\
\hline & & MEAN & & -0.07 & -0.17 \\
\hline & & MEDIAN & & -0.03 & -0.12 \\
\hline & & QUARTILE 1 & & -0.08 & -0.26 \\
\hline & & QUARTILE 3 & & 0.00 & -0.04 \\
\hline & & ST. DEVIATION & & 0.12 & 0.39 \\
\hline & & $\mathbf{N}$ & & 14 & 13 \\
\hline
\end{tabular}

$\mathrm{n} / \mathrm{a}=$ data are not available 
Wijantini-The Indirect Costs of FinancialDistress in Indonesia

\section{Continued from Table 3}

Panel D. Firms which were financially healthy in 1998 but became financially distressed during 1999-2002

The Indirect Costs of Financial Distress (CFDop) are estimated by average changes of the adjusted industry EBITDA / Total Sales changes from a year before the onset of distress to 2002. CFDs are estimated by average changes of the adjusted inflation and industry sales changes from a year before the onset of distress to 2002. Negative (positive) signs indicate the lower (higher) adjusted performance at the exit year, therefore showing the costs (value creation) estimation.

\begin{tabular}{|c|c|c|c|c|c|}
\hline No. & Company & $\begin{array}{l}\text { Industry Classification } \\
\text { (Datastream) }\end{array}$ & $\begin{array}{c}\text { Onset } \\
\text { Distress } \\
\text { Year }\end{array}$ & CFDop & CFDs \\
\hline 1 & Keramika Indonesia & Building Materials & 1999 & -0.34 & -0.14 \\
\hline 2 & Multi Agro Persada & Electronic Equipment & 1999 & 0.06 & 1.99 \\
\hline 3 & Sunson Textile & Clothing and Footwear & 2000 & 0.06 & 0.02 \\
\hline
\end{tabular}

Panel E. Firms which were financially healthy in 1997 and 1998 but became financially distressed during 1999-2002 and exited from the distress by 2002

The Indirect Costs of Financial Distress (CFDop) are estimated by annualised changes of industry adjusted operating profit (EBITDA/Total Sales) from a year before the onset of distress to the exit year. CFDs are estimated by annualised changes of industry-adjusted sales from a year before the onset of distress to the exit year. Negative (positive) signs indicate the lower (higher) adjusted performance at the exit year; therefore showing the costs (value creation) estimation.

\begin{tabular}{|c|c|c|c|c|c|c|}
\hline No. & Company & $\begin{array}{c}\text { Industry Classification } \\
\text { (Datastream) }\end{array}$ & $\begin{array}{c}\text { Onset } \\
\text { Distress } \\
\text { Year } \\
\end{array}$ & $\begin{array}{c}\text { Exit } \\
\text { Distress } \\
\text { Year } \\
\end{array}$ & CFDop & CFDs \\
\hline 1 & Intikeramik Alamsari & Building Materials & 1999 & 2001 & 0.10 & -0.07 \\
\hline 2 & Nipress Tbk & Electrical Equip. & 2000 & 2001 & 0.03 & -0.36 \\
\hline 3 & Pioneerindo Gourmet & Hotels and Catering & 2000 & 2002 & -0.07 & -1.20 \\
\hline
\end{tabular}




\section{Continued from Table 3}

\section{Panel F: The Indirect Costs of Financial Distress: Firms with an exit year and Firms} still in distress in 2002

For firms with an exit year, the indirect costs of financial distress (CFDop) are estimated by changes of industry-adjusted operating profit (EBITDA/Total Sales) from the onset of distress year to the exit year. CFDs are estimated by annualized changes of industry-adjusted sales from the onset of distress year to the exit year. For firms still in distress by 2002. CFDop* is estimated by annualized changes of the adjusted industry EBITDA / Total Sales from a year before the onset of distress to 2002. CFDs* are estimated by annualized changes of the adjusted industry sales from a year before the onset of distress to 2002. Negative (positive) signs indicate the lower (higher) adjusted performance at the exit year, therefore showing the costs (value creation) estimation.

\begin{tabular}{|c|c|c|c|c|c|}
\hline \multicolumn{3}{|c|}{ Firms with the exit year } & \multicolumn{3}{|c|}{ Firms still in distress in 2002} \\
\hline Name of Company & CFDop & CFDs & Name of Company & CFDop* & CFDs* \\
\hline Astra Graphia & -0.10 & -0.29 & Apac Citra & 0.02 & 0.68 \\
\hline Charoen Pokphand & -0.13 & -0.53 & Argha Karya Prima & -0.04 & -0.12 \\
\hline Fast Food Indonesia & -0.02 & 0.20 & Davomas Abadi & -0.03 & -0.20 \\
\hline Kedawung Setia Ind'1 & -0.04 & -0.22 & Dharmala Intiland & -0.23 & $\mathrm{n} / \mathrm{a}$ \\
\hline Lionmesh Prima & -0.04 & -0.05 & Indomobil Sukses & -0.01 & -0.18 \\
\hline Modern Photo Film & 0.00 & 0.03 & Intraco Penta & 0.00 & 0.02 \\
\hline Prima Alloy Steel & -0.03 & -0.07 & Panasia Indosyntex & -0.04 & -0.03 \\
\hline Semen Cibinong & -0.31 & 0.19 & Primarindo Asia & 0.01 & -0.04 \\
\hline Intikeramik Alamsari & 0.10 & -0.07 & Surabaya Agung & -0.17 & -0.04 \\
\hline Nipress Tbk & 0.03 & -0.36 & Surya Hidup Satwa & -0.09 & -1.12 \\
\hline \multirow[t]{7}{*}{ Pioneerindo Gourmet } & -0.07 & -1.20 & Surya Semesta & -0.41 & -0.26 \\
\hline & & & Texmaco Jaya & -0.03 & -0.32 \\
\hline & & & Trias Sentosa Tbk & 0.04 & -0.48 \\
\hline & & & Zebra Nusantara & -0.01 & -0.09 \\
\hline & & & Keramika Indonesia & -0.34 & -0.14 \\
\hline & & & Multi Agro Persada Tbk & 0.06 & 1.99 \\
\hline & & & Sunson Textile & 0.06 & 0.02 \\
\hline MEAN & -0.06 & -0.22 & MEAN & -0.07 & -0.02 \\
\hline MEDIAN & -0.04 & -0.07 & MEDIAN & -0.03 & -0.11 \\
\hline QUARTILE 1 & -0.09 & -0.33 & QUARTILE 1 & -0.09 & -0.22 \\
\hline QUARTILE 3 & -0.01 & -0.01 & QUARTILE 3 & 0.01 & -0.02 \\
\hline ST. DEVIATION & 0.10 & 0.40 & ST. DEVIATION & 0.14 & 0.64 \\
\hline $\mathbf{N}$ & 11 & 11 & $\mathbf{N}$ & 17 & 16 \\
\hline
\end{tabular}




\section{Table 4. Descriptive Statistics and Pearson [Spearman] Correlation Coeffi- cients for Variables}

In panel $\mathrm{A}, \mathrm{CFDop}$ is the indirect costs of financial distress estimated by measuring annualized changes of operating profit from the onset of distress to the resolution year for 11 firms and annualized industry-adjusted changes of operating profit from the onset of distress to 2002 for 17 firms. In panel B, CFDs are estimated indirect costs of financial distress by measuring annualized industry-adjusted changes of sales from the onset of distress to the resolution year for 11 firms and annualized industry adjusted changes of sales from the onset of distress to 2002 for 16 firms. LEV is the ratio of total debt to total capital at the onset of distress. COMPLEX is the number of the firm's creditors at the onset of distress. BANK is the portion of bank loan to total debt at the onset of distress. DLOW is 1 if the industry return was in the low quartile (below $25^{\text {th }}$ percentile) over the period when costs of financial distress are calculated, 0 otherwise. Industry performance is equal-weighted return to firms in the same industry over the period when costs of financial distress are calculated. LSIZE is the log value of market value of outstanding total capital at the onset of distress. Spearman coefficients are in parentheses.

* Significant at the 10 percent level; ** Significant at the 5 percent level; *** Significant at the 1 percent level

Panel A: CFD is estimated with Operating Profit Approach

\begin{tabular}{|c|c|c|c|c|c|c|}
\hline Item & CFDop & LEV & COMPLEX & BANK & DLOW & LSIZE \\
\hline CFDop & $\begin{array}{c}1.000 \\
{[1.000]}\end{array}$ & & & & & \\
\hline LEV & $\begin{array}{c}0.332 * \\
{[0.381 * *]}\end{array}$ & $\begin{array}{c}1.000 \\
{[1.000]}\end{array}$ & & & & \\
\hline COMPLEX & $\begin{array}{c}0.341^{*} \\
{\left[0.348^{*}\right]}\end{array}$ & $\begin{array}{c}0.131 \\
{\left[0.337^{*}\right]}\end{array}$ & $\begin{array}{c}1.000 \\
{[1.000]}\end{array}$ & & & \\
\hline BANK & $\begin{array}{c}-0.113 \\
{[-0.255]}\end{array}$ & $\begin{array}{c}0.103 \\
{[0.110]}\end{array}$ & $\begin{array}{c}0.221 \\
{[0.172]}\end{array}$ & $\begin{array}{c}1.000 \\
{[1.000]}\end{array}$ & & \\
\hline DLOW & $\begin{array}{c}0.429 * * \\
{[0.211]}\end{array}$ & $\begin{array}{c}0.189 \\
{[0.039]}\end{array}$ & $\begin{array}{c}-0.146 \\
{[-0.162]}\end{array}$ & $\begin{array}{c}0.016 \\
{[0.034]}\end{array}$ & $\begin{array}{c}1.000 \\
{[1.000]}\end{array}$ & \\
\hline LSIZE & $\begin{array}{c}0.346^{*} \\
{\left[0.346^{*}\right]}\end{array}$ & $\begin{array}{c}0.088 \\
{\left[0.376^{* *}\right]}\end{array}$ & $\begin{array}{c}0.601^{* * * *} \\
{\left[0.616^{* * *}\right]}\end{array}$ & $\begin{array}{c}0.154 \\
{[0.122]}\end{array}$ & $\begin{array}{c}-0.124 \\
{[-0.088]}\end{array}$ & $\begin{array}{c}1.000 \\
{[1.000]}\end{array}$ \\
\hline $\begin{array}{l}\text { Mean } \\
\text { St. Dev }\end{array}$ & $\begin{array}{c}-0.065 \\
0.123\end{array}$ & $\begin{array}{l}0.808 \\
0.170\end{array}$ & $\begin{array}{c}12.679 \\
9.051\end{array}$ & $\begin{array}{l}0.660 \\
0.240\end{array}$ & $\begin{array}{l}0.285 \\
0.460\end{array}$ & $\begin{array}{c}20.142 \\
1.405\end{array}$ \\
\hline
\end{tabular}


Gadjah Mada International Journal of Business, May - August 2007, Vol. 9, No. 2

Continued from Table 4

Panel B: CFD is estimated with Sales Approach

\begin{tabular}{|c|c|c|c|c|c|c|}
\hline Item & CFDop & LEV & COMPLEX & BANK & DLOW & LSIZE \\
\hline CFDs & $\begin{array}{c}1.000 \\
{[1.000]}\end{array}$ & & & & & \\
\hline LEV & $\begin{array}{c}0.087 \\
{[0.126]}\end{array}$ & $\begin{array}{c}1.000 \\
{[1.000]}\end{array}$ & & & & \\
\hline AFFILI & $\begin{array}{c}-0.134 \\
{[-0.086]}\end{array}$ & $\begin{array}{c}-0.377 * \\
{[-0.306]}\end{array}$ & & & & \\
\hline COMPLEX & $\begin{array}{c}0.347^{*} \\
{[0.133]}\end{array}$ & $\begin{array}{c}0.112 \\
{[0.307]}\end{array}$ & $\begin{array}{c}1.000 \\
{[1.000]}\end{array}$ & & & \\
\hline BANK & $\begin{array}{c}-0.034 \\
{[-0.105]}\end{array}$ & $\begin{array}{c}0.070 \\
{[0.083]}\end{array}$ & $\begin{array}{c}0.197 \\
{[0.146]}\end{array}$ & $\begin{array}{c}1.000 \\
{[1.000]}\end{array}$ & & \\
\hline DLOW & $\begin{array}{l}0.351 * \\
{[0.212]}\end{array}$ & $\begin{array}{c}0.151 \\
{[0.000]}\end{array}$ & $\begin{array}{c}-0.199 \\
{[-0.229]}\end{array}$ & $\begin{array}{c}-0.058 \\
{[-0.038]}\end{array}$ & $\begin{array}{c}1.000 \\
{[1.000]}\end{array}$ & \\
\hline LSIZE & $\begin{array}{c}0.123 \\
{[0.092]}\end{array}$ & $\begin{array}{c}0.066 \\
{\left[0.357^{*}\right]}\end{array}$ & $\begin{array}{c}0.592 * * * \\
{[0.601 * * *]}\end{array}$ & $\begin{array}{c}0.124 \\
{[0.093]}\end{array}$ & $\begin{array}{c}-0.180 \\
{[-0.174]}\end{array}$ & $\begin{array}{c}1.000 \\
{[1.000]}\end{array}$ \\
\hline Mean & 0.099 & 0.803 & 12.44 & 0.650 & 0.259 & 20.103 \\
\hline St. Dev & 0.554 & 0.171 & 9.137 & 0.238 & 0.446 & 1.415 \\
\hline
\end{tabular}

operating profit and sales approach provides results that show a median (mean) of the costs of between four percent (eight percent) and six percent (nine percent). We thoroughly checked them in the years after their exit year until the end of year 2002 whether the companies renegotiated their restructured loans. Panel B shows that one company (Kedawung Setia Industrial) failed to fulfill its debt agreement, and renegotiated with its creditors for a second time. The next category (Panel C) lists firms which were in financial distress in 1997 and 1998, and were identified to be still in distress in 2002. For these firms, we calculated the annualized changes in each firm's performance from a year before the onset of distress to the end of 2002. The sales approach estimates higher annualized costs of financial distress, with a median (mean) of 12 percent (17 percent), than operating profit estimation, with a median (mean) of three percent (seven percent). Panel D and E mainly classify firms which were financially healthy before 1998, and became distressed after 1998. Finally, in Panel F, we summarize all cost estimation into two major categories: firms which had a resolution year and firms which were still in distress in 2002. The overall results of the operating profit approach indicates that the median (mean) values of indirect financial distress cost measured by the annualized drop in industry-adjusted EBITDA/Sales are between three percent (six percent) and four percent (seven percent) annu- 
ally. The sales approach shows a wider range of the costs estimation with a standard deviation of more than 40 percent; the median (mean) values of the costs are between seven percent (two percent) and 11 percent (22 percent) per year.

Panels A and B of Table 4 present Pearson and Spearman's Rho correlation coefficients. Both operating profit and sales approach confirm that the indirect cost of financial distress is positively correlated with COMPLEX. It supports the fifth hypothesis that a higher number of creditors may cause higher conflicts of interest in restructuring problem loans. Accordingly, this may raise the indirect cost of financial distress. Furthermore, the panels also show that poor industry performance (DLOW) has an effect on the costs. Low industry performance during the time of distress positively contributes to the costs. The result supports Shleifer and Vishny's (1992) prediction that the costs of financial distress may be higher if the firm's industry performs poorly. Moreover, both panels also show a significant correlation between size of company (LSIZE) and the number of creditors (COMPLEX). Greater size is positively associated with the number of bank lenders. The high association between them may cause a multicollinearity problem in regression results. Thomas (1997) is concerned that the multicollinearity will present larger standard errors, and hence the estimation results will lack precision. However, unless the multicollinearity is perfect, there is no violation against the classical assumptions. Even with a high degree of multicollinearity, the Ordinary Least Square estimators retain unbiased estimates.

Table 5 presents the results of both full and simple regressions on each determinant of the indirect cost of financial distress. Regression(1) shows that poor industry performance (DLOW) significantly affects the costs with a p-value of 0.0077 . However, the evidence presented here must be carefully assessed along with its limitations. For instance, regression specification tests (RESET) indicate that the equation has been misspecified in some way or other (Thomas 1997). Regression (2) and (3) present no significant evidence that size, leverage, complexity of capital structure, degree of bank loans, and industry performance affect the estimated indirect cost of financial distress.

In simple regressions analysis presented in Regressions (4) to (8), they demonstrate supports for most of the hypotheses. Regression (4) shows that the cost has a positive relationship with the size of firms ( $p$-value $=0.07$ ). Meanwhile, Regression (5) supports the view that higher leverage positively affects the costs with pvalue $=0.08$. Regression (6) substantiates the financial distress theory about the existence of conflicts of interest in distress resolution which may increase the costs of financial distress. The association between the number of creditors, as a proxy for higher conflicts, and the costs is positive and significant 
Gadjah Mada International Journal of Business, May - August 2007, Vol. 9, No. 2

\section{Table 5. Regressions of the Indirect Costs of Financial Distress on Firm Characteristics}

All regressions except Regression (2) and (3) apply the indirect cost of financial distress (CFD) measured as changes of industry adjusted operating profit on firm characteristics. Regressions (2) and (3) apply the CFD measured as changes of industry adjusted sales on firm characteristics for full samples. All regressions except Regressions (2) and (3) consist of 28 financially distressed firms while Regressions (2) and (3) consist of 27 financially distressed firms. LSIZE is log value of SIZE measured by market value of outstanding total capital at the onset of distress. LEV is the ratio of total debt to total capital at the onset of distress. COMPLEX is the number of firm's creditors at the onset of distress. BANK is the portion of bank loan to total debt at the onset of distress. Dlow is 1 if the industry return was in the low quartile (below $25^{\text {th }}$ percentile) over the period when costs of financial distress are calculated, 0 otherwise. Industry performance is equal-weighted return to firms in the same industry over the period that costs of financial distress are calculated. p-values are in parentheses.

\begin{tabular}{|c|c|c|c|c|c|c|c|c|}
\hline & (1) & (2) & (3) & (4) & (5) & (6) & (7) & (8) \\
\hline Intercept & $\begin{array}{l}-0.508 \\
{[0.1423]}\end{array}$ & $\begin{array}{l}0.95745 \\
{[0.6117]}\end{array}$ & $\begin{array}{l}-0.217 \\
{[0.7025]}\end{array}$ & $\begin{array}{l}-0.550 \\
{[0.1044]}\end{array}$ & $\begin{array}{l}-0.130 \\
{[0.2498]}\end{array}$ & $\begin{array}{l}0.005 \\
{[0.8836]}\end{array}$ & $\begin{array}{l}0.103 \\
{[0.1541]}\end{array}$ & $\begin{array}{l}0.032 \\
{[0.2198]}\end{array}$ \\
\hline LSIZE $(+)$ & $\begin{array}{l}0.022 \\
{[0.2023]}\end{array}$ & $\begin{array}{l}-0.062 \\
{[0.5134]}\end{array}$ & & $\begin{array}{l}0.030^{*} \\
{[0.0705]}\end{array}$ & & & & \\
\hline $\operatorname{LEV}(+)$ & $\begin{array}{l}0.152 \\
{[0.1984]}\end{array}$ & $\begin{array}{l}0.349 \\
{[0.5871]}\end{array}$ & $\begin{array}{l}0.343 \\
{[0.5881]}\end{array}$ & & $\begin{array}{l}0.241^{*} \\
{[0.0834]}\end{array}$ & & & \\
\hline COMPLEX $(+)$ & $\begin{array}{l}0.004 \\
{[0.1617]}\end{array}$ & $\begin{array}{l}0.022 \\
{[0.1388]}\end{array}$ & $\begin{array}{l}0.017 \\
{[0.1674]}\end{array}$ & & & $\begin{array}{l}0.004 * \\
{[0.0750]}\end{array}$ & & \\
\hline BANK $(+)$ & $\begin{array}{l}-0.125 \\
{[0.1376]}\end{array}$ & $\begin{array}{l}-0.107 \\
{[0.8148]}\end{array}$ & $\begin{array}{l}-0.11 \\
{[0.8085]}\end{array}$ & & & & $\begin{array}{l}-0.058 \\
{[0.5679]}\end{array}$ & \\
\hline Dlow $(+)$ & $\begin{array}{l}0.125^{* * *} \\
{[0.0077]}\end{array}$ & $\begin{array}{l}-0.403 \\
{[0.1177]}\end{array}$ & $\begin{array}{l}-0.39 \\
{[0.1229]}\end{array}$ & & & & & $\begin{array}{l}0.115^{* *} \\
{[0.0225]}\end{array}$ \\
\hline $\operatorname{Adj} R^{2}$ & 0.39 & 0.09 & 0.11 & 0.120 & 0.110 & 0.116 & 0.012 & 0.184 \\
\hline F ratio & $\begin{array}{l}4.106^{* * *} \\
{[0.0087]}\end{array}$ & $\begin{array}{l}1.272 \\
{[0.3126]}\end{array}$ & $\begin{array}{l}1.518 \\
{[0.2313]}\end{array}$ & $\begin{array}{l}3.557^{*} \\
{[0.0705]}\end{array}$ & $\begin{array}{l}3.240^{*} \\
{[0.0834]}\end{array}$ & $\begin{array}{l}3.441^{*} \\
{[0.0750]}\end{array}$ & $\begin{array}{l}0.334 \\
{[0.5679]}\end{array}$ & $\begin{array}{l}5.883^{* *} \\
{[0.0225]}\end{array}$ \\
\hline AR & $\begin{array}{l}2.213 \\
{[0.1354]}\end{array}$ & $\begin{array}{l}0.39227 \\
{[0.6809]}\end{array}$ & $\begin{array}{l}0.62256 \\
{[0.5466]}\end{array}$ & $\begin{array}{l}2.119 \\
{[0.1420]}\end{array}$ & $\begin{array}{l}0.713 \\
{[0.4998]}\end{array}$ & $\begin{array}{l}2.289 \\
{[0.1231]}\end{array}$ & $\begin{array}{l}0.253 \\
{[0.7779]}\end{array}$ & $\begin{array}{l}0.420 \\
{[0.6613]}\end{array}$ \\
\hline Normality & 3.743 & $9.996 * * *$ & $9.196^{* *}$ & $6.527^{* *}$ & $9.344 * * *$ & $10.999 * * *$ & $19.331 * * *$ & 2.294 \\
\hline $\mathrm{Chi}^{\wedge} 2(2)$ & [0.1539] & {$[0.0067]$} & {$[0.0101]$} & {$[0.0382]$} & {$[0.0093]$} & {$[0.0041]$} & {$[0.0001]$} & {$[0.3176]$} \\
\hline $\mathrm{Xi}^{\wedge} 2$ & $\begin{array}{l}2.299 * \\
{[0.0899]}\end{array}$ & $\begin{array}{l}0.267 \\
{[0.9714]}\end{array}$ & $\begin{array}{l}0.351 \\
{[0.9157]}\end{array}$ & $\begin{array}{l}0.958 \\
{[0.3984]}\end{array}$ & $\begin{array}{l}0.510 \\
{[0.6066]}\end{array}$ & $\begin{array}{l}0.305 \\
{[0.7397]}\end{array}$ & $\begin{array}{l}0.412 \\
{[0.6665]}\end{array}$ & $\begin{array}{l}33.167^{* * *} \\
{[0.0000]}\end{array}$ \\
\hline RESET & $\begin{array}{l}5.345^{*} \\
{[0.0310]}\end{array}$ & $\begin{array}{l}1.157 \\
{[0.2947]}\end{array}$ & $\begin{array}{l}0.051 \\
{[0.8225]}\end{array}$ & $\begin{array}{l}0.362 \\
{[0.5524]}\end{array}$ & $\begin{array}{l}0.860 \\
{[0.3624]}\end{array}$ & $\begin{array}{l}0.060 \\
{[0.8082]}\end{array}$ & $\begin{array}{l}0.342 \\
{[0.5638]}\end{array}$ & \\
\hline
\end{tabular}

*** Significant at the $1 \%$ level, ${ }^{* *}$ Significant at the $5 \%$ level and, ${ }^{*}$ Significant at the $10 \%$ level. 
Wijantini-The Indirect Costs of FinancialDistress in Indonesia

Table 6. Cross-Sectional Determinants of the Costs of Financial Distress

Panel A: Andrade and Kaplan (1998) Results •

\begin{tabular}{|c|c|c|c|c|c|c|}
\hline & $\begin{array}{c}\text { Log HLT } \\
\text { Value } \\
(-)\end{array}$ & $\begin{array}{c}\text { Default } \\
(-)\end{array}$ & $\begin{array}{c}\text { Time In } \\
\text { Distress } \\
(+)\end{array}$ & $\begin{array}{c}\text { Log \# of } \\
\text { Securities } \\
(-)\end{array}$ & $\begin{array}{c}\text { Bank Debt/ } \\
\text { Total Debt } \\
(+)\end{array}$ & $\begin{array}{c}\text { Industry } \\
\text { Return } \\
(+)\end{array}$ \\
\hline Coefficient & $-0.163 * *$ & 0.270 & 0.002 & $-0.351 * *$ & $-0.811^{*}$ & -0.324 \\
\hline St. Errors & 0.068 & 0.275 & 0.007 & 0.160 & 0.474 & 0.256 \\
\hline Adj. $R^{2}$ & 0.14 & & 0.01 & 0.12 & 0.06 & -0.00 \\
\hline $\mathrm{N}$ & 30 & & & & & \\
\hline
\end{tabular}

Panel B: Current Sample Results

\begin{tabular}{|c|c|c|c|c|c|}
\hline & $\begin{array}{c}\text { LSIZE } \\
(+)\end{array}$ & $\begin{array}{c}\text { LEV } \\
(+)\end{array}$ & $\begin{array}{c}\text { COMPLEX } \\
(+)\end{array}$ & $\begin{array}{c}\text { BANK } \\
(+)\end{array}$ & $\begin{array}{c}\text { DLOW } \\
(+)\end{array}$ \\
\hline Coefficient & $0.030^{*}$ & $0.241 *$ & $0.004 *$ & -0.058 & $0.115^{* *}$ \\
\hline St. Errors & 0.016 & 0.134 & 0.002 & 0.100 & 0.047 \\
\hline Adj. $R^{2}$ & 0.12 & 0.11 & 0.12 & 0.01 & 0.18 \\
\hline $\mathrm{N}$ & 28 & & & & \\
\hline
\end{tabular}

* Statistically significant at the $10 \%$ level.

**Statistically significant at the $5 \%$ level.

*** Statistically significant at the $1 \%$ level.

In Andrade and Kaplan's study (1998), the costs of distress are estimated as the difference between the value of total predistress capital and the total capital realized during distress. Pre-distress figures correspond to the last fiscal year before distress onset. The estimated pre-distress value of total capital for each company is calculated as [product of median industry (net capital/ EBITDA) and company EBITDA] plus company cash balances at pre-distress year-end. Industry medians are based on the universe of firms in the same Value Line industry classification as the company. EBITDA is earnings before interest, taxes, depreciation and amortization. Value of total capital realized during distress is the present value of all payments to capital made from distress onset up to resolution (inclusive) discounted back to the pre-distress year. Payments to capital include cash interest and debt principal repaid, dividends paid, equity repurchased and total value received by capital at distress resolution, net proceeds from new equity and debt issues. HLT value is the capital value of the HLT when the HLT is completed. HLT is Highly Leveraged Transactions. Default equals 1 if the firm defaulted on its debt and 0 otherwise. Time In Distress is the number of months between the onset of distress and the resolution of that distress. Number (\#) of securities is the number of different debt and preferred stock securities in the post-HLT capital structure. Bank Debt to total debt is as measured in the year before financial distress. Industry returns dummy variables equal lif the industry return was in the third quartile from the onset of distress until resolution and 0 otherwise. In the present study, the CFD is estimated as the annualized changes of industry adjusted operating profit from the onset of distress year to the exit year for 11 firms while for the other 16 firms, the costs are estimated as annualized changes of the adjusted industry operating profit from a year before the onset of distress to 2002. LSIZE is log value of SIZE measured by market value of outstanding total capital at onset distress the log value of SIZE is included in the analysis because the association between SIZE and CFD is previously identified as a nonlinear relationship. LEV is the ratio of total debt to total capital at the onset of distress. COMPLEX is the number of firm's creditors at the onset of distress. BANK is the portion of bank loan to total debt at the onset of distress. Dlow is 1 if the industry return was in the low quartile (below $25^{\text {th }}$ percentile) over the period when costs of financial distress are calculated, 0 otherwise. Industry performance is equal-weighted return to firms in the same industry over the period when costs of financial distress are calculated.

- Source: Andrade and Kaplan (1998). The Journal of Finance Vol. 53. No. 5. page 1485. 
at $p$-value $=0.07$. Regression (7) provides no evidence of a positive association between the bank loan reliance and costs. Finally, Regression (8) shows the effect of industry performance on costs. The result indicates that poor performance in the industry positively affects costs ( $p$-value $=0.02$ ). In other words, there is a tendency that the difficulty of selling assets at fair values can increase costs when competing firms, as potential buyers, are also in financial trouble. Again, the results presented here must be carefully assessed along with its limitations. A significant problem with these simple regressions is the omission of relevant variables from the relationship. The estimators will be biased unless the omitted variables are orthogonal to other independent variables (Thomas 1997; Ryan et al. 2002, among others).

In Table 6, we examined the crosssectional determinants of the costs on firm characteristics found in prior research. The work of Andrade and Kaplan (1998) was used as the benchmark since its approach is the closest to the one applied in this study. No study on the costs estimation has so far been conducted in Indonesia. Under different legal and financial market circumstances, we agree that the tables convey few comparisons for each study. However, it may be highlighted that both studies provide evidence that the size of firm and complexity affect costs. The number of securities is used as a proxy for capital structure complexity in Andrade and Kaplan's research while this study applies the number of creditors as the proxy for complexity. Their research offers evidence that costs are negatively related to the size of firm. It indicates that there are important fixed costs to restructuring in the American system, while in Indonesia we predict that low fixed costs and size are more positively correlated to the degree of conflicts of interest. A high correlation coefficient between size and the number of creditors (COMPLEX) supports the consistency of the view that complexity increases the indirect cost of financial distress.

\section{Conclusions}

This research studies sample of Indonesian financially distressed firms which survived in 1997-2002. Most of the firms turned out to be financially distressed due to the Asian crisis. It clarifies the factors which may contribute to the costs by classifying its explanatory variables. More importantly, it presents quantitative estimates of the indirect cost of financial distress and its determinants. In order to measure the cost, this study estimates the annualized changes in industry-adjusted operation profit and sales from a year before the onset of distress to the resolution year. Some firms were still negotiating their loans until the end of the sample period (2002); for such firms, the cost estimated the annualized changes until 2002. Using those approaches, the median of indirect financial distress cost is estimated between three and 11 percent annually. 
Wijantini-The Indirect Costs of FinancialDistress in Indonesia

To the extent that the direct cost of financial distress reduces reported operating income, the estimated costs are overstated. The average time in distress for firms in the sample is divided into two categories. 17 firms (61 percent) were still in distress by the end of 2002 , giving an average time in distress of more than four years. 11 firms (39 percent) obtained debt renegotiation agreements by 2002 with an average time in distress of 2.6 years. The simple regressions analysis suggest that the indirect cost of financial distress significantly increases with size, leverage, number of creditors, and poor industry performance, but is not related to group affiliation, political connection, and degree of bank loan reliance. Therefore, the findings provide a weak support for the financial distress theory which suggests that conflicts of interest render the costs of financial distress.

\section{The Limitations of the Study}

The main shortcoming of this study is the small size of sample and the lack of data in the sample period. The sample contains only 28 financially distressed firms. The small sample reduces confidence and limits the possibility of drawing general conclusions from the results. The sample period of 1997-2002 offers both advantages and disadvantages to the aims of the study. The systemic crisis beginning in mid-1997 offers a bigger sample of financially distressed firms than a normal period would; nevertheless, it also offers disadvantages since it creates a more complex condition in resolving financial distress.

In order to minimize the uncertainty effect on firm performance, we prefer to estimate the costs on the basis of accounting information which we consider to be able to provide more reliable data than does stock market performance during the sample period. However, accounting information may have some inherent shortcomings for the purpose of the study; for instance, it does not reflect investors' perceptions regarding distress issues.

In particular, the study measures the ex-post indirect costs of financial distress for the surviving firms in Indonesia. Ideally, the costs of financial distress apply to both liquidated and surviving firms in the sample. Therefore, the estimated costs could have been higher if the defunct firms are included. Moreover, the measurement does not consider the effect of option values, economic factors on the costs, for example, the shift of the demand and supply 
Gadjah Mada International Journal of Business, May - August 2007, Vol. 9, No. 2

\section{References}

Aghion, P. and Bolton, P. 1992. An incomplete contract approach to financial contracting. Review of Economics Studies 59: 473 - 494.

Altman, E. I. 1984. A further empirical investigation of bankruptcy cost question. Journal of Finance 39 (4) (September).

Altman, E. I. 1993. Evaluating the chapter 11 bankruptcy reorganization process. Columbia Business Law Review.

Altman, E. I., and A. C. Eberhart. 1994. Do previousity provisions protect a bondholder's investment? Journal of Portfolio Management 20: 67 - 75.

Andrade, G., and S. N. Kaplan. 1998. How costly is financial (not economic) distress? Evidence from highly leveraged transactions that became distressed. Journal of Finance 53 (5) (October).

Ang, J. S., J. H. Chua, and J. J. McConnell. 1982. The administrative costs of corporate bankruptcy: A note. Journal of Finance 37 (1) (March): 219 - 226.

Baird, D. G. 1986. The uneasy case for corporate reorganizations. Journal of Legal Studies 40.

Betker, B. 1998. The security price effects of public debt defaults. Journal of Financial Research 21: 17 - 35.

Branch, B. 2002. The costs of bankruptcy: A review. International Review of Financial Analysis 11: 39 - 57.

Brown, D. T. 2000. Liquidity and liquidation: Evidence from real estate investment trusts. Journal of Finance 55 (1): 469-485.

Bulow, J., and J. Shoven. 1978. The bankruptcy decision. Bell Journal of Economics 9: 437-456.

Castanias, R. 1983. Bankruptcy risk and optimal capital structure. Journal of Finance 38 (December).

Chen, G. M., and L. J. Merville. 1999. An analysis of the underreported magnitude of the total indirect costs of financial distress. Review of Quantitative Finance and Accounting 13: 277-293.

Cutler, D. M., and L. H. Summers. 1988. The costs of conflict resolution and financial distress: Evidence from the Texaco-Pennzoil litigation. Journal of Economics 157.

Gertner, R., and D. S. Scharfstein. 1991. A theory of workouts and the effects of reorganization law. Journal of Finance 46 (4): 1189-1222.

Giammarino, R. M. 1989. The resolution of financial distress. Reviewof Financial Studies 2: $25-47$.

Gilson, S. C., K. John, and L. H. P. Lang. 1990. Troubled debt restructuring: An empirical study of private reorganization of firms in default. Journal of Financial Economics 27: 315-353.

Guffey, D. M., and W. T. Moore. 1991. Direct bankruptcy costs: Evidence from the trucking industry. Financial Review 26 (2) (May): 223-235. 
Wijantini-The Indirect Costs of FinancialDistress in Indonesia

Haugen, R. A., and L. W. Senbet. 1978. The insignificant of bankruptcy costs to the theory of optimal capital structure. Journal of Finance 33 (2) (May): 383-393.

Helwege, J. 1999. How long do junk bonds spend in default? Journal of Finance 54 (1): 341-357.

Hoshi, T., A. Kashyap, and D. Scharfstein. 1990. The role of banks in reducing the costs of financial distress in Japan. Journal of Financial Economics 67 (September).

Hotchkiss, E. S. 1995. Postbankruptcy performance and management turnover. Journal of Finance 50: 3-21.

Jensen, M. C. 1991. Corporate control and the politics of finance. Journal of Applied Corporate Finance 4 (2) (Summer): 13 - 33.

Kaplan, S. N., and R. S. Ruback. 1995. The valuation of cash flow forecasts: An empirical analysis. Journal of Finance 50 (4) (September): 1059-1093.

Kim, C. E. 1998. The effects of asset liquidity: Evidence from the contract drilling industry. Journal of Financial Intermediation 7 (2): 151-176.

Kraus, A., and R. Litzenberger. 1973. A state preference model of optimal financial leverage. Journal of Finance 28 (4): 911-922.

Kruse, T. A. 2002. Asset liquidity and the determinants of asset aales by poorly performing firms. Financial Management 31(Winter): 107-129.

Modigliani, F., and M. Miller. 1958. The cost of capital, corporate finance and the theory of investment. American Economic Review 48 (3): 261-197.

Modigliani, F. and Miller, M. H. 1963. Corporate income taxes and the cost of capital: A correction. American Economic Review 53 (June): 433-443.

Myers, S. C., and N. S. Majluf. 1984. Corporate financing and investment decisions when firms have information that investors do not have. Journal of Financial Economics 13: $187-221$.

Noveas, W., and L. Zingales. 1995. Capital structure choice when managers are in control: Entrenchment versus efficiency. Chicago: University of Chicago.

Opler, T. C., and S. Titman. 1994. Financial distress and corporate performance. Journal of Finance 49 (3): 1015-1040.

Pulvino, T. C. 1998. Do asset fire sales exist? An empirical investigation of commercial aircraft transactions. Journal of Finance 53 (3): 939-978.

Ryan, B., R. W. Scapens, and M Theobald. 2002. Research Method and Methodology in Finance and Accounting ( $2^{\text {nd }} \mathrm{ed}$.): Thomson.

Scott, J. H. 1976. A theory of optimal capital structure. The Bell Journal of Economics: 33-54.

Shleifer, A., and R. Vishny. 1992. Liquidation value and debt capacity: A market equilibrium approach. Journal of Finance 47: 1343-1365.

Stone, B. K. 1977. Discussant remarks on J Warner's bankruptcy costs: Some evidence. Journal of Finance 32 (May).

Thomas, R. L. 1997. Modern Econometrics: An Introduction. Prentice Hall. 
Gadjah Mada International Journal of Business, May - August 2007, Vol. 9, No. 2

Tomasic, R. 2001. Some challenges for insolvency system reform in Indonesia. Melbourne, Australia: Victoria University: 1-19.

Warner, J. 1977. Bankruptcy costs: Some evidence. Journal of Finance 32 (May).

Weiss, L. A. 1990. Bankruptcy resolution: Direct costs and violation of previousity of claims. Journal of Financial and Economics 27 (October) (Issue: 2): 285-314.

White, M. J. 1983. Bankruptcy costs and the new bankruptcy code. Journal of Finance 38 (2) (May).

Wijantini. 2006. Voluntary disclosure in the annual reports of financially distressed companies in Indonesia. Gadjah Mada International Journal of Business 8 (3): 343365 . 